\title{
Product Competitiveness and Market Penetration in South Sulawesi: Mapping of Leading Export Commodities
}

\author{
Indraswati Tri Abdi Reviane ${ }^{\mathrm{a}, *}$, Abdul Hamid Paddu ${ }^{\mathrm{a}}$, Muhammad Jibril Tajibu $^{\mathrm{a}}$ \\ ${ }^{a}$ Department of Economics, Faculty of Economics and Business, Universitas Hasanuddin, Makassar, Indonesia
}

\begin{abstract}
The competitiveness and market penetration of South Sulawesi's top export goods are examined in this study. The major export commodities are mapped using the Klassen typology and export product dynamic technique based on their competitiveness, market penetration power, and export-dynamic. The "Revealed Comparative Advantage" and "Index of Export Market Penetration" indicators are used in this study to assess the competitiveness and market penetration of each main export product. This research will also look at the factors that influence the competitiveness and market penetration of these top export commodities, as well as their capacity to boost economic development and build a productive and peaceful business environment in South Sulawesi. The major export goods from South Sulawesi, according to this study, are nickel, lac, fish, and cocoa, all of which have great market penetration and strong competitiveness. Meanwhile, salts are South Sulawesi's most important export commodity, with high competitiveness but little market penetration. Coffee, meat and fish preparations, and food wastes are examples of commodities with high competition and little market penetration. Furthermore, fruits, oilseeds, and sugar are commodities with high market penetration but poor competitiveness. Six commodities are in the rising star position, while five are in the loose opportunity position.
\end{abstract}

Keywords: competitiveness, market penetration, leading export commodities

\section{INTRODUCTION}

In the last two years, the volume of world trade has decreased due to the trade war between the United States and China, which was followed by the Covid 19 pandemic. This has resulted in a slowdown in global economic growth, including in Indonesia. Slowing economic growth in all countries has an impact on Indonesia's international trade, where the proportion of international trade is quite large in absorbing Indonesia's national production.

In anticipating further impacts that may be detrimental to the country's economy, Indonesia is currently required to further increase the competitiveness of export products in the world market so that the volume of its exports can increase further.

Although Indonesia is now increasingly open to international trade, Indonesian producers cannot still access other markets. The position of the Indonesian market that experienced

\footnotetext{
* Author in correspondence,

Email address: indraswati@fe.unhas.ac.id (Indraswati Tri Abdi Reviane)
}

ISSN: 2549-3221 (Print) 2549-323X (Online)

DOI: $10.26487 /$ hebr.v5i3.3407 the largest increase in market contribution was in products that were not dynamic, this was not too expected, while the increase in market contribution for products that had fast growth and was highly expected, was only around 34.7 percent, and was the second-lowest after India.

Moreover, losing the market contribution of dynamic products, Indonesia ranks second after Taiwan. This of course must get more attention from the government so that the position of the Indonesian market can be even better. Furthermore, Indonesia consists of several provinces with different characteristics, of which South Sulawesi Province is one of them with superior agricultural and maritime characteristics, of course, it has various comparative advantages.

However, generally, these regions, including South Sulawesi Province, admit that it is difficult to know with certainty the comparative advantages possessed by each of these regions which will ultimately have an impact on the competitiveness of these products in the international market. This is what usually becomes a burden for developing countries such as Indonesia in facing the era of globalization.

Concerns about products that, although following the regional comparative advantage, do not have great competitiveness and sufficient market penetration with similar products in 
the international market. It is known that commodity competitiveness and export market penetration are the indicators of a country's success in international trade. This low competitiveness and market penetration can be influenced by several factors, such as the low level of efficiency and labor productivity, the level of technological progress used is still low, marketing strategies are still lacking, etc.

\section{LITERATURE REVIEW}

This section will discuss some theoretical and empirical reviews that have been done by some previous researchers related to competitiveness and market penetration.

\subsection{Theoretical Background}

Classical trade theory is built on the labor theory of value which assumes that: (1) labor is the only factor of production that is the easiest to adjust if there is an imbalance and is relatively homogeneous, (2) labor productivity is constant, so the opportunity cost is also constant and the resulting scale is constant, (3) the production function of each item differs from one country to another. (4) factors of production (labor) are only free to move within the same country, but there is no factor mobility between countries.

Based on the assumptions above, Smith stated that each country has an absolute advantage in producing a product where that country is more efficient than other countries in producing it. According to Smith, each country should specialize in producing goods in which they have an absolute advantage in producing those goods and exchange them for goods produced by other countries in which they do not have an absolute advantage in producing them. By specializing according to their respective absolute advantages, both countries can enjoy the benefits of their trade, or in other words, international trade becomes a positive-sum game, a situation in which all trading countries benefit from trade, although there may be some who enjoy trade. bigger than the others.

Furthermore, according to Ricardo in his theory known as the theory of comparative advantage, he emphasized that a country will specialize in producing the goods that they produce most efficiently, and buy the goods that they are least efficient at producing from other countries, although in fact, they can produce all these goods more efficiently than other countries.

Several definitions can be used to see the comparative advantage of a country, namely: (i) a country is said to have a comparative advantage in producing a good in which it has the greatest absolute advantage or the least absolute disadvantage. (ii) a country is said to have a comparative advantage in producing a good if and only if the opportunity cost of that commodity relative to other commodities is lower than that of other countries.

An economy that is open to trade will produce two dynamic advantages, namely, first, free trade can increase the supply of state resources such as increasing the supply of labor and capital resources from abroad available domestically; second, free trade will also increase the efficiency of countries in using their resources. For example, economies with large production scales, technology, management, stimulation of competition, etc. So, the dynamic advantage (resource supply and efficiency increases) will shift the country's production possibilities frontier (PPF) to the outside.

The previous trade theory, both classical theory and neoclassical theory, both said that the basis for trade, namely the difference in commodity prices between countries, was caused by differences in the production function between countries. However, Swedish economists Eli Heckscher (1919) and Bertil Ohlin (1933) provide a further and different explanation of comparative advantage. They argue that price differences between countries can still occur even though the production function is the same in all countries. This is because the comparative advantage is measured by differences in the abundance of production factors owned by a country.

In addition, this modern theory has begun to abandon the classical assumption that the only factor of production is labor. This theory explains that there are other factors of production besides labor, namely capital. Each country differs in the abundance of factors of production, where these differences will have an impact on differences in the costs of these factors. The more abundant a factor, the lower the cost of that factor. Conversely, the rarer a factor, the higher the cost of that factor.

The Heckscher-Ohlin theory predicts that each country will specialize in producing and exporting goods intensively using the country's relatively abundant factors of production. Instead, the country will import goods that intensively use factors of production that are relatively scarce in the country. It can be concluded that the basic idea of the H-O theory is: (i) each commodity differs in the intensity of use of the factors of production. A commodity is said to be capital intensive if and only if it uses a higher ratio of capital to labor than other commodities. (ii) ach country differs in the abundance of factors of production.

The abundance of production factors owned by a country can be explained by using two criteria, namely economic criteria (price criteria) and physical criteria. The economic criterion (price) is used by comparing the price ratio of the two factors of production, where a country (A) is said to be a country with abundant capital relative to other countries (B), if and only if it is in an autarky condition (before the trade), the price of the factors of production of capital relative to labor is cheaper in country A than in country B.

The physical abundance criterion is used by comparing the ratio of the physical quantities of the two factors of production, in which a country (A) is said to be relatively capital abundant compared to other countries (B), if and only if it is in an autarky condition (before the trade occurs), the physical amount of capital production factors per unit of labor is more in country A than in country B.

Furthermore, according to the Technological Gap theory, every commodity that uses more advanced technology and more sophisticated innovation will have a comparative advantage compared to similar commodities with relatively low technology.

However, the comparative advantage as measured by tech- 
nological advantages (innovations) is usually not long-lived because its competitors will quickly respond by imitating the technology. At that time the comparative advantage of the commodity will decrease. Therefore, to maintain its comparative advantage, producers of these commodities are required to continue to research to find innovations for their outputs, so that the comparative advantage of these commodities will never be lost. Furthermore, The Product Life Cycle theory was introduced by Raymond Vernon in the mid-1960s. Vernon agrees that most of the new output was originally produced in America (19451975).

The company thinks that maintaining production facilities closer to the market and closer to the decision-making center of the company is the best. This is due to the uncertainty and risk inherent in introducing new products to the market, where demand for most new products tends to be based rather than on price factors. This theory says that every commodity has a life cycle, in which the commodity's comparative advantage begins when the commodity is first introduced to the market. After some time enjoying the advantages of its comparative advantage, similar commodities will appear, so the comparative advantage of these goods will decrease.

\subsection{Previous Studies}

Comparative advantage in India and ASEAN, that as a member of ASEAN, Indonesia has a stable comparative advantage in the industrial sector. In addition, India's comparative advantage structure is similar to several countries in ASEAN so that India can face trade competition against countries in ASEAN. For example, Malaysia and Indonesia with RCA index numbers of 14.4 and 22.08 respectively for Vegetation fats and oils, fats, and waxes indicate a possible trade relationship with India which has an average RCA index of only 0.666 . Furthermore, only Indonesia has a comparative advantage in manufacturing commodities and India has the opportunity to compete because it has an abundant workforce (Ahuja, 2020).

Indonesian and Vietnam coffee exports in the ASEAN market are competitive. Indonesia has an average RCA score of 10.16 and Vietnam's 53.44. Meanwhile, the results of the EPD analysis show that the coffee trade between Indonesia and Vietnam is in the rising star quadrant, which means that the export trade performance is fast and dynamic where the growth rate of Indonesian coffee exports continues to increase in line with the increasing share of exports in ASEAN (Zuhdi and Suharno, 2015).

Empirical analysis of per capita income growth, the value of FTA, and distance are important factors that determine future export prospects (Bano and Scrimgeour, 2012). The comparative advantage and bilateral trade between Australia and China are driven by demand for each other's goods (Sheng and Song, 2008). Comparative advantage and competitive advantage found that a strong comparative advantage is seen in developing countries in the transportation and travel services sector (Seyoum, 2007). Economic growth is proven to increase the comparative advantage of developing countries through technological improvements and capital increases that gradually increase the scale of production (Riaz, 2011).
India faces competition not only from Southeast Asian countries but from several African countries and other countries such as Mexico. Since the comparative export performance index and comparative advantage only measure trade data, factors such as communication, transportation, storage, distribution, quality, meeting the special quarantine requirements of the importing country are not taken into account. As a result, the actual performance of India's exports in the global market was not as expected. On the other hand, there has been a substantial increase in the volume of horticultural exports since 2005. Other measures include integrated training programs to improve the quality, productivity of selected fruit commodities, and setting up facilities for disinfestation. A more efficient supply chain will make Indian horticulture more globally competitive and create conditions for mutually beneficial trade negotiations and benefit from existing comparative advantages in different markets (Bhattacharyya, 2012).

Indonesia can improve to optimize opportunities because the growth rate of commodity exports is still lower than demand. Most of Indonesia's export products in the Chinese market are categorized as leading retreats and lagging retreats. In the case of ACFTA, Indonesia can improve export performance in the Chinese market (Widyasanti, 2010).

The competitiveness of Turkey and its development using two index numbers, namely the revealed comparative advantage (RCA) and the comparative export performance (CEP). Using regression analysis, they find that if Turkey competes with other countries in the EU market, the price of its products will have a significant effect on its export demand function (Serin and Civan, 2008).

Analyzes comparative advantage in India and China concludes that although there are similarities in the structure of comparative advantage, there is no correlation between the manufacturing sectors of India and China in the global economy (Batra and Khan, 2005)

Comparative advantage, economic growth, and free trade have found that specialization according to comparative advantage will benefit a country and economy governed by free competition or without government intervention, only market forces are not sufficient to provide adequate incentives, necessary for production so that producers use available resources and trade according to comparative advantage (Gallardo, 2005).

The competitiveness and flow of trade patterns from Turkey to the EU at the sectoral level. They used several measures of competitiveness and found that the process of economic integration between Turkey and the EU has a significant effect on trade patterns, comparative advantage, and product competitiveness (Utkulu and Seymen, 2004).

The coefficient calculated from the RCA index, liberalization of trade restrictions, and changes in external controls caused China's general export pattern to shift towards a more consistent pattern with comparative advantage (Yue and Hua, 2002).

\section{RESEARCH METHODS}

The research method used in this study was Library Research, as a form of research that utilized available means of 
the library in the forms of books, journals, data, and other empirical studies. These materials can be obtained from the library directly or via the internet. The data used in this study were secondary data obtained from various data sources, such as the International Financial Statistics of the IMF, World Bank, Bank Indonesia reports, Central Bureau of Statistics, and other sources. All data used in this study were the annual data for each variable of study from 2016 until 2020.

The object of this research is the export products of South Sulawesi. All of these products will be mapped and adjusted to the advantages possessed by each region so that the area can be used as a center for the production of these products, and then this research will focus on the superior products produced by the region by using the characteristics of the regional data to see how much the influence of competitiveness and market penetration of export commodities can encourage an increase in export volume so that in the end it can encourage economic growth and social welfare.

This study surveyed the products that have been exported to South Sulawesi to determine the level of excellence possessed by each of these products. Next, calculate the competitiveness and penetration power of the export market for each of these commodities, then make a mapping of export commodities by adjusting the advantages possessed by the regions which will eventually become production centers for these products.

To identify the leading sector or commodity in South Sulawesi, the Location Quotient (LQ) analysis tool is used:

$$
L Q=\frac{V_{i} / V_{t}}{Y_{i} / Y_{t}}
$$

where:
$V_{i}: \quad$ total Gross Regional Domestic Products sector $i$ at Regency/City or total export of commodities i in South Sulawesi,
$V_{t}: \quad$ total GRDP of Regency/City or Total Ex- port of South Sulawesi,
$Y_{i}: \quad$ total GRDP of sector i at South Sulawesi or Total Export of commodity i Indonesia,
$Y_{t}: \quad$ total GRDP of South Sulawesi or total ex- ports of Indonesia.

To identify the competitiveness of the commodity which is the leading sector, the Revealed Comparative Advantage (RCA) calculation will be used with the following formula:

$$
R C A_{i j}=\frac{X_{i j} / X_{t j}}{X_{i w} / X_{t w}}
$$

where,

$R C A_{i j}$ : index of comparative advantage of commodity $\mathrm{i}$ in area $\mathrm{j}$,

$X_{i j}$ : export value of commodity $\mathrm{i}$ area $\mathrm{j}$,

$X_{t j}$ : total value of regional exports $\mathrm{j}$,
$X_{i w}$ : export value of commodity $\mathrm{i}$ in the world,

$X_{t w}$ : total value of world exports.

To identify the market penetration power of the commodity export which is the leading sector, the calculation of the Index of Export Market Penetration (IEMP) will be used with the following formula:

$$
I E M P=\frac{S_{X_{i}}}{T C_{m}}
$$

where:

$$
\begin{aligned}
& S_{X_{i}} \text { : Hummels-Klenow (products) Intensive } \\
& \text { Margin is measured by the export share of }
\end{aligned}
$$

Furthermore, mapping the leading export commodities in South Sulawesi based on their competitiveness, market penetration power, and their dynamic position used the Klassen Typology analysis and Export Product Dynamic method.

The Export Product Dynamic (EPD) method will be used to answer the problem of the dynamic position of competitiveness and world market penetration of the leading export commodities of South Sulawesi Province.

Horizontal axis $\mathrm{X}$, describes the market share growth of leading export commodities in South Sulawesi Province in the world market:

$$
X=\frac{\sum_{n=1}^{n}\left(\frac{X_{i j}}{W_{i j}}\right)_{n}-\sum_{n=1}^{n}\left(\frac{X_{i j}}{W_{i j}}\right)_{n-1}}{N}
$$

While the Y axis depicts the growth of the export market share of South Sulawesi Province in the world market:

$$
Y=\frac{\sum_{n=1}^{n}\left(\frac{X_{T}}{W_{T}}\right)_{n}-\sum_{n=1}^{n}\left(\frac{X_{T}}{W_{T}}\right)_{n-1}}{N}
$$

where:

$X_{i j}: \quad \begin{aligned} & \text { export value of the leading commodity i in } \\ & \text { South Sulawesi Province. }\end{aligned}$
$W_{i j}: \begin{aligned} & \text { export value of the world's leading com- } \\ & \text { modity } \mathrm{i} .\end{aligned}$
$X_{T}: \begin{aligned} & \text { total export value of South Sulawesi } \\ & \text { Province, }\end{aligned}$
$W_{T}: \quad \begin{aligned} & \text { total world's export value, } \\ & N: \text { number of importing countries. }\end{aligned}$

\section{RESULT AND DISCUSSION}

\subsection{Result}

\subsubsection{Leading Sectors and Commodities of South Sulawesi}

From the results of the study, it was found that the leading sectors of South Sulawesi as shown in the Table 1, the region 
in South Sulawesi have advantages in the agriculture, forestry, and fisheries sectors. The five regions that have the highest advantages in the three sectors are Luwu, Takalar, Bone, North Luwu, and Pinrang.

Meanwhile, there are four regions that have the highest advantages in the mining sector, that are Maros, Pangkep, Wajo, and East Luwu. The manufacturing industry sector is also superior in four regions, namely Makassar, Maros, Sidrap, and Pangkep.

The advantages in these sectors are mostly due to the abundance of natural production factors so that the trade pattern of the regions in South Sulawesi is still based on these advantages.

Based on these leading sectors, further analysis is to find out what commodities are the leading commodities in each of the five leading sectors by using Location Quotient (LQ) analysis.

Basically, this technique presents a relative comparison between the ability of a commodity in South Sulawesi and the ability of the same commodity on a national or Indonesian scale. This LQ calculation uses South Sulawesi export value data by commodity (HS 2) which consists of 23 commodities, compared to Indonesia's export value data by commodity (HS2), which consists of 23 commodities in 2016-2020 in units of million US dollars.

Furthermore, from the five leading sectors, there are eleven commodities which are the leading commodities of South $\mathrm{Su}-$ lawesi with the largest contribution to the total exports of South Sulawesi, and there are two commodities that are actually not classified as a leading commodity but are now starting to get a lot of attention from producers, as shown in the following Table 2 .

The highest advantage commodity is nickel, with an average LQ calculation from 2016-2020 of 139.61. Nickel commodities include construction materials, various manufactured goods, industrial equipment, and manufacturing. The second position is oilseed commodities which include corn, sesame, cashew, and soybean commodities with an average LQ calculation from 2016-2020 of 49.04. The position of the three leading export commodities is lac, gums, and resin commodities which include copal gum, vegetables, and vegetation fats and oils with an average LQ calculation from 2016-2020 reaching 30.36.

\subsubsection{Competitiveness of Leading Export Commodities of South Sulawesi}

Revealed Comparative Advantage (RCA) analysis is used to measure the level of competitiveness of the leading export commodities of South Sulawesi. The results of the calculation of the RCA analysis in this study are categorized into three groups. First, the competitiveness group is very strong (***) when the RCA value is above 15; second, a strong competitiveness (**) group for commodities with an RCA value greater than or equal to 1 , but less than or equal to 15 ; and third, the weak competitiveness (*) group for the RCA value is below 1 .

Furthermore, the development of competitiveness of the leading export commodities of South Sulawesi Province from 2016 to 2020 , can be seen in Table 3 .

The results of the calculation of the RCA value of the leading export commodities of South Sulawesi, five commodities have very strong competitiveness, namely nickel, with an average RCA value in the last five years of 484.54. Then, followed by lac, gums and resin, and cocoa with RCA values of 57.51 and 33.19, respectively. Fish and shrimp, as well as salt sulfur, and calcium, are also included in the category of commodities with very strong competitiveness, with RCA values of 17.78 and 16.06, respectively. This figure indicates that these commodities have very strong competitiveness as evidenced by the average $\mathrm{RCA}$ value $>15$.

Furthermore, six commodities have strong competitiveness. Among them are oil seeds, with an average RCA value in the last five years of 14.51. Then, followed by coffee, tea, maté, spices; and fruits with RCA values of 9.16 and 7.10, respectively. Preparation of meat and fish; and residues and waste from the food industries are also included in the category of commodities with strong competitiveness, with RCA values of 4.28 and 3.80, respectively. In addition, conventional sugar also has strong competitiveness with RCA values of 1.32. RCA values below 15 but still above 1, indicate that these commodities have strong competitiveness.

\subsubsection{Market Penetration for Leading Export Commodities of South Sulawesi}

Analysis of international market penetration is used to measure the extent to which the export of a commodity is absorbed by the international market. The value of the index number obtained shows how strong a region's export commodities penetrate the international market. This is possible if the export share of the commodity is large, as well as the number of regional export destination countries. If the $I E M P_{i j}$ calculation is close to 1 , it means that the exported commodity has a greater ability to penetrate the international market. The lower the smaller than 1 (closer to 0 ), the lower the penetration power of the regional export commodity.

Furthermore, the market penetration power of these leading export commodities can be seen in the Table 4:

In this study, the results of the market penetration analysis are categorized into three groups. The first group is commodities with high market penetration (***) if the market penetration index is greater than or equal to 0.0002 ; the second group is commodities with moderate market penetration $(* *)$ if the market penetration rate is less than 0.0002 and greater than or equal to 0.0001 , and the third group is commodities with low market penetration $(*)$ when the market penetration is below 0.0001 .

The results of the $I E M P_{i j}$ calculation for the export commodities of South Sulawesi during 2016-2020 show that Nickel (HS Code 75) is an export commodity with the highest market penetration capability (0.002) and export destination countries average 18 countries per year with a market share of around 3 percent of trade world Nickel. Then, the high market penetration was followed by exports of lac, gums, and resin (0.00027); fish and shrimp (0.00023); and cocoa (0.00023). Commodities classified as having moderate market penetration are: preparations of meat and fish (0.0018); coffee, tea, and spices (0.0018); residues and waste from the food industry (0.00012), and salt, sulfur, and calcium (0.00011). Meanwhile, the market penetration rate, which is relatively low, the calculated $I E M P_{i j}$ 
Table 1: Leading Sectors of Region in South Sulawesi 2020

\begin{tabular}{lccccc}
\hline \multirow{2}{*}{ Region } & \multicolumn{5}{c}{ Leading Sector } \\
\cline { 2 - 6 } & Agriculture & Forestry & Fishery & Mining & Manufacture \\
\hline Bantaeng & 1.44 & 1.44 & 1.44 & - & - \\
Barru & 1.71 & 1.71 & 1.71 & - & - \\
Bone & 2.3 & 2.3 & 2.3 & - & - \\
Bulukumba & 1.87 & 1.87 & 1.87 & - & - \\
Enrekang & 1.87 & 1.87 & 1.87 & - & - \\
Gowa & 1.36 & 1.36 & 1.36 & - & - \\
Jeneponto & 2.08 & 2.08 & 2.08 & - & - \\
Kep. Selayar & 2.06 & 2.06 & 2.06 & - & - \\
Luwu & 2.4 & 2.4 & 2.4 & - & - \\
Luwu Utara & 2.26 & 2.26 & 2.26 & - & - \\
Maros & - & - & - & 2.22 & 1.63 \\
Pinrang & 2.21 & 2.21 & 2.21 & - & - \\
Sidrap & 1.48 & 1.48 & 1.48 & - & 1.01 \\
Sinjai & 2.05 & 2.05 & 2.05 & - & - \\
Soppeng & 1.39 & 1.39 & 1.39 & - & - \\
Takalar & 2.32 & 2.32 & 2.32 & - & - \\
Tana Toraja & 1.14 & 1.14 & 1.14 & - & - \\
Wajo & 1.52 & 1.52 & 1.52 & 3.06 & - \\
Luwu Timur & - & - & - & 10.04 & - \\
Pangkep & - & - & - & 1.81 & 3.66 \\
Makassar & - & - & - & - & 1.38 \\
\hline
\end{tabular}

Table 2: Location Quotient Results of Export Commodities in South Sulawesi 2016-2020

\begin{tabular}{|c|c|c|c|c|c|c|c|c|}
\hline No & Code & Commodity & 2016 & 2017 & 2018 & 2019 & 2020 & Average \\
\hline 1 & 75 & Nickel & 122.75 & 160.94 & 152.1 & 133.51 & 128.75 & 139.61 \\
\hline 2 & 12 & Oil Seeds & 39.73 & 63.75 & 52.24 & 46.46 & 43.04 & 49.04 \\
\hline 3 & 13 & Lac. Gums. and Resin & 15.35 & 13.73 & 34.33 & 46.14 & 42.25 & 30.36 \\
\hline 4 & 25 & Salt. Sulfur. and Calcium & 13.77 & 25.36 & 26.54 & 23.5 & 19.1 & 21.65 \\
\hline 5 & 18 & Cocoa & 16.11 & 7.88 & 4.64 & 3.3 & 2.45 & 6.87 \\
\hline 6 & 8 & Fruits & 10.17 & 5.41 & 2.04 & 1.89 & 1.43 & 4.19 \\
\hline 7 & 16 & Preparation of Meat and Fish & 3.97 & 4.37 & 0.96 & 1.98 & 2.1 & 2.67 \\
\hline 8 & 3 & Fish and Shrimp & 4.7 & 3.46 & 1.71 & 1.34 & 1.94 & 2.63 \\
\hline 9 & 17 & Sugars and Sugar Confectionery & 2.44 & 2.69 & 1.73 & 2.38 & 1.13 & 2.08 \\
\hline 10 & 23 & Residues and waste from the food industries & 2.28 & 2.22 & 1.81 & 1.91 & 1.33 & 1.91 \\
\hline 11 & 9 & Coffee. Tea. and Spices & 1.16 & 0.44 & 0.88 & 0.66 & 2.3 & 1.09 \\
\hline
\end{tabular}

value is very close to zero because the export destinations are only 1-2 destination countries with a small international share. There are fruits (0.000051) and sugar and sugar confectionery (0.000041).

Based on the results of the $I E M P_{i j}$ calculation, these superior commodities need attention to ensure future sustainability and improve the quality of exported products so that their penetration power can be stronger in the international market. Meanwhile, for those who are detected with weak penetration power, they should not be ignored, further studies are needed on what things influence them to be able to formulate recommendations and efforts to increase their market penetration power.

Exports of South Sulawesi commodities are very much dominated by raw materials. These goods are generally exported to countries that have strong capital capabilities so that they can establish large industries, such as the United States, Japan, Korea, and China. When juxtaposed with the value-added theory, the value-added of a commodity occurs because it undergoes processing, transportation, or storage process in production. Based on this understanding, changes in the value of raw materials that have undergone large processing treatments can be estimated to increase income. It is only necessary to pay attention to whether the capacity of the domestic industry is qualified and the competitiveness of the goods produced by the domestic industry will be able to compete with products from other countries in the international market. 
Table 3: Competitiveness of Leading Export Results in South Sulawesi

\begin{tabular}{clrrrrrr}
\hline Code & Commodity & $\mathbf{2 0 1 6}$ & $\mathbf{2 0 1 7}$ & $\mathbf{2 0 1 8}$ & $\mathbf{2 0 1 9}$ & $\mathbf{2 0 2 0}$ & Average \\
\hline 3 & Fish and Shrimp & 16.46 & 18.54 & 18.23 & 17.52 & 18.17 & $17.78^{* * *}$ \\
8 & Fruits & 7.25 & 8.5 & 7.25 & 7.15 & 5.32 & $7.10^{* *}$ \\
9 & Coffee, Tea, Maté, and Spices & 5 & 5.26 & 9.98 & 11.47 & 14.1 & $9.16^{* *}$ \\
12 & Oil Seeds & 12.34 & 12.17 & 16.01 & 17.44 & 14.59 & $14.51^{* *}$ \\
13 & Lac, Gums, and Resin & 20.92 & 18.71 & 64.32 & 102.33 & 81.29 & $57.51^{* * *}$ \\
16 & Preparation of Meat and Fish & 3.14 & 5 & 5.11 & 4.25 & 3.89 & $4.28^{* *}$ \\
17 & Sugar And Sugars Confectionery & 1.33 & 1.35 & 1.17 & 1.88 & 0.87 & $1.32^{* *}$ \\
18 & Cocoa & 45.9 & 41.11 & 30.59 & 31 & 17.34 & $33.19^{* * *}$ \\
23 & Residues and waste from the food industries & 3.9 & 3.94 & 3.91 & 4.25 & 3.01 & $3.80^{* *}$ \\
25 & Salt, Sulphur, and Calcium & 6.3 & 13.37 & 19.47 & 21.33 & 19.84 & $16.06^{* * *}$ \\
75 & Nickel & 416.84 & 551.84 & 506.31 & 458.95 & 488.78 & $484.54^{* * *}$ \\
\hline
\end{tabular}

Table 4: Market Penetration Index of Export Commodities in South Sulawesi 2016-2020

\begin{tabular}{clrrrrrr}
\hline Code & Commodity & $\mathbf{2 0 1 6}$ & $\mathbf{2 0 1 7}$ & $\mathbf{2 0 1 8}$ & $\mathbf{2 0 1 9}$ & $\mathbf{2 0 2 0}$ & Average \\
\hline 3 & Fish and Shrimp & 0.00025 & 0.00029 & 0.00015 & 0.00025 & 0.00023 & $0.00023^{* * *}$ \\
8 & Fruits & 0.000070 & 0.000070 & 0.000040 & 0.000040 & 0.000040 & $0.00005^{*}$ \\
9 & Coffee, Tea, Maté, and Spices & 0.000200 & 0.000100 & 0.000200 & 0.000200 & 0.000300 & $0.00018^{* *}$ \\
12 & Oil Seeds & 0.000050 & 0.000040 & 0.000060 & 0.000060 & - & $*$ \\
13 & Lac, Gums, and Resin & 0.000200 & 0.000200 & 0.000300 & 0.000300 & 0.000300 & $0.00027^{* * *}$ \\
16 & Preperation of Meat and Fish & 0.000230 & 0.000200 & 0.000100 & 0.000200 & 0.000200 & $0.00018^{* *}$ \\
17 & Sugars and Sugar Confectionery & 0.000030 & 0.000040 & 0.000040 & 0.000040 & 0.000060 & $0.00004^{*}$ \\
18 & Cocoa & 0.000300 & 0.000200 & 0.000300 & 0.000200 & 0.000200 & $0.00023^{* * *}$ \\
23 & Residues and waste from the food industries & 0.000100 & 0.000100 & 0.000100 & 0.000100 & 0.000100 & $0.00012^{* *}$ \\
25 & Salt, Sulphur and Calcium & 0.000070 & 0.000070 & 0.000100 & 0.000100 & 0.000200 & $0.00011^{* *}$ \\
75 & Nickel & 0.001500 & 0.001800 & 0.001500 & 0.002100 & 0.001900 & $0.002^{* * *}$ \\
\hline
\end{tabular}

\subsubsection{Mapping of the Leading Export Commodities of South Sulawesi Province}

Based on the competitiveness and market penetration of these commodities, we can map them using the Klassen typology as follows:

\subsubsection{Competitiveness of Leading Export Commodities of South Sulawesi}

Revealed Comparative Advantage (RCA) analysis is used to measure the level of competitiveness of the leading export commodities of South Sulawesi. The results of the calculation of the RCA analysis in this study are categorized into three groups. First, the competitiveness group is very strong (***) when the RCA value is above 15; second, a strong competitiveness (**) group for commodities with an RCA value greater than or equal to 1 , but less than or equal to 15 ; and third, the weak competitiveness (*) group for the RCA value is below 1 .

Furthermore, the development of competitiveness of the leading export commodities of South Sulawesi Province from 2016 to 2020 , can be seen in Table 3 .

The results of the calculation of the RCA value of the leading export commodities of South Sulawesi, five commodities have very strong competitiveness, namely nickel, with an average RCA value in the last five years of 484.54. Then, followed by lac, gums, and resin, and cocoa, with RCA values of 57.51 and 33.19, respectively. Fish and shrimp, as well as salt, sulfur, and calcium, are also included in the category of commodities with very strong competitiveness, with RCA values of 17.78 and 16.06, respectively. This figure indicates that these commodities have very strong competitiveness as evidenced by the average $\mathrm{RCA}$ value $>15$.

Furthermore, six commodities have strong competitiveness. Among them are oil seeds, with an average RCA value in the last five years of 14.51. Then followed by coffee, tea, maté, and spices, and fruits with RCA values of 9.16 and 7.10, respectively. Preparation of meat and fish; and residues and waste from the food industries are also included in the category of commodities with strong competitiveness, with RCA values of 4.28 and 3.80 , respectively. In addition, sugar and sugar conventional also have strong competitiveness with RCA values of 1.32. RCA values below 15 but still above 1 , indicate that these commodities have strong competitiveness.

\subsubsection{Market Penetration for Leading Export Commodities of South Sulawesi}

Analysis of international market penetration is used to measure the extent to which the export of a commodity is absorbed by the international market. The value of the index number obtained shows how strong a region's export commodities penetrate the international market. This is possible if the export 
share of the commodity is large, as well as the number of regional export destination countries. If the $I E M P_{i j}$ calculation is close to 1 , it means that the exported commodity has a greater ability to penetrate the international market. The lower the number is less than 1 (closer to 0 ), the lower the penetration power of the regional export commodity.

Furthermore, the market penetration power of these leading export commodities can be seen in Table 4 .

In this study, the results of the market penetration analysis are categorized into three groups. The first group is commodities with high market penetration $(* * *)$ if the market penetration index is greater than or equal to 0.0002 ; the second group is commodities with moderate market penetration $(* *)$ if the market penetration rate is less than 0.0002 and greater than or equal to 0.0001 , and the third group is commodities with low market penetration $(*)$ when the market penetration is below 0.0001 .

The results of the $I E M P_{i j}$ calculation for the export commodities of South Sulawesi during 2016-2020 show that nickel (HS Code 75) is an export commodity with the highest market penetration capability (0.002) and an export destination country average of 18 countries per year, with a market share of around 3 percent of the trade world nickel. Then, the high market penetration was followed by exports of lac, gums, and resin (0.00027); fish and shrimp (0.00023); and cocoa (0.00023). Commodities classified as having moderate market penetration are preparations of meat and fish (0.0018); coffee, tea, and spices (0.0018); residues and waste from the food industry $(0.00012$ and salt, sulfur, and calcium (0.00011). Meanwhile, the market penetration rate, which is relatively low, the calculated $I E M P_{i j}$ value is very close to zero because the export destinations are only 1-2 destination countries with a small international share.

Based on the results of the $I E M P_{i j}$ calculation, these superior commodities need attention to ensure future sustainability and improve the quality of exported products so that their penetration power can be stronger in the international market. Meanwhile, those who are detected with weak penetration power should not be ignored. Further studies are needed on what things influence them to be able to formulate recommendations and efforts to increase their market penetration power.

Exports of South Sulawesi commodities are very much dominated by raw materials. These goods are generally exported to countries that have strong capital capabilities so that they can establish large industries, such as the United States, Japan, Korea, and China. When juxtaposed with the value-added theory, the value-added of a commodity occurs because it undergoes processing, transportation, or storage process in production. Based on this understanding, changes in the value of raw materials that have undergone large processing treatments can be estimated to increase income. It is only necessary to pay attention to whether the capacity of the domestic industry is qualified and whether the competitiveness of the goods produced by the domestic industry will be able to compete with products from other countries in the international market.

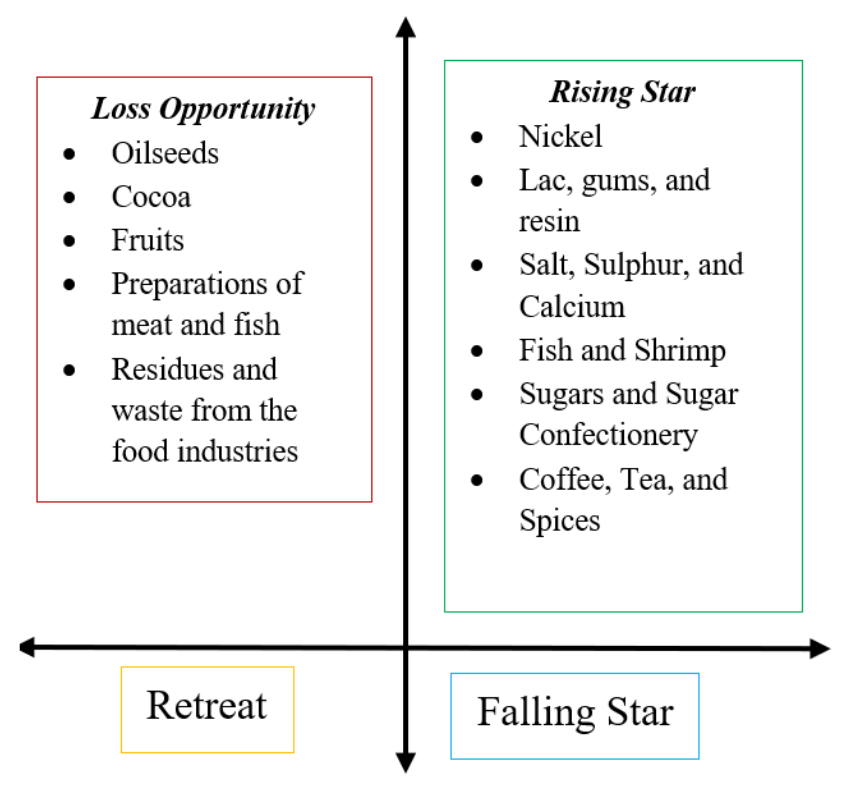

Figure 1: Matrix dynamic competitiveness leading export commodities of South Sulawesi

\subsubsection{Mapping of the Leading Export Commodities of South Sulawesi Province}

Based on the competitiveness and market penetration of these (commodities, we can map them using the Klassen typology as Table 5.

\section{Export Product Dynamics (EPD)}

Export Product Dynamics (EPD) is an indicator that measures the market position of a country's product for a particular market purpose is Export Product Dynamics (EPD). This measure can help export performance across regions around the world. Observing the dynamic competitiveness position of leading export commodities, mapped into 4 categories; Loss Opportunity, Rising Star, Retreat, and Falling Star, based on research (Esterhuizen, 2006).

Based on the average EPD value of leading export commodities in South Sulawesi 2011 - 2018 shown in Figure 1, most of those commodities are in the rising star position. This shows that the commodities nickel; lac, gums, and resin; salt, sulfur, and calcium; fish and shrimp; sugars and sugar confectionery; coffee, tea, and spices are dynamic commodities, it means that these products have increased market share in the world during 2018 - 2020. Loss Opportunity conditions occur in oilseeds, cocoa, fruits, preparations of meat and fish; and residues and waste from the food industries, which have decreased competitiveness so that the resulting products lose the opportunity to reach exports in the international market. Meanwhile, there are no commodities in Retreat and Falling Star conditions.

These commodities are categorized based on the results of a more detailed Export Product Dynamics analysis. Table 6 shows the $\mathrm{X}$ value and $\mathrm{Y}$ value. The $\mathrm{X}$ value identifies the market share of the leading export commodities in South Sulawesi to the world and the Y value identifies the share of South Su- 
Table 5: The Klassen Typology of Export Commodities in South Sulawesi 2016-2020

\begin{tabular}{|c|c|c|c|}
\hline \multirow[b]{2}{*}{ Market Penetration } & \multicolumn{3}{|c|}{ Competitiveness } \\
\hline & Very Strong & Strong & Weak \\
\hline High & $\begin{array}{l}\text { - Nickel } \\
\text { - Lac, Gums, And Resin } \\
\text { - Fish and Shrimp } \\
\text { - Cocoa }\end{array}$ & - & - \\
\hline Medium & - Salt, Sulphur, and Calcium & $\begin{array}{l}\text { - Preparation of Meat and Fish } \\
\text { - Residues and waste from the food in- } \\
\text { dustries } \\
\text { - Coffee, Tea, Maté, and Spices }\end{array}$ & - \\
\hline Low & & $\begin{array}{l}\text { - Fruits } \\
\text { - Oil Seeds } \\
\text { - Sugars and Confectionery }\end{array}$ & - \\
\hline
\end{tabular}

lawesi total exports to total world exports.

The highest commodity market share in the world is Nickel, which is identified through the highest $X$ value 2960.45. Meanwhile, the commodity that has the lowest market share in the world is Preparations of meat and fish with $\mathrm{X}$ value -87.65 .

Table 6: Export Product Dynamic

\begin{tabular}{clcc}
\hline Code & Commodity & $\mathbf{X}$ & $\mathbf{Y}$ \\
\hline 75 & Nickel & 2960.45 & $3.92583 .10^{-6}$ \\
9 & Coffee, Tea, Maté, and & 62.46 & $3.92583 .10^{-6}$ \\
& Spices & & \\
13 & Lac, Gums, and Resin & 21.54 & $3.92583 .10^{-6}$ \\
3 & Fish and Shrimp & 10.68 & $3.93000 .10^{-6}$ \\
25 & Salt, Sulphur, and Cal- & 5.03 & $3.92583 .10^{-6}$ \\
& cium & & \\
17 & Sugars and Sugar Confec- & 0.0022 & $3.92583 .10^{-6}$ \\
& tionery & & \\
23 & Residues and waste from & -0.01 & $3.92583 .10^{-6}$ \\
& the food industries & & \\
18 & Cocoa & -0.65 & $3.92583 .10^{-6}$ \\
8 & Fruits & -2.42 & $3.92583 .10^{-6}$ \\
12 & Oil Seeds & -60.84 & $3.92583 .10^{-6}$ \\
16 & Preparations of Meat and & -87.65 & $3.92583 .10^{-6}$ \\
& Fish & & \\
\hline
\end{tabular}

\subsection{Discussion}

This study used Revealed Comparative Advantage (RCA) analysis, Index of Export Market Penetration (IEMP) analysis, and Export Product Dynamic (EPD) analysis. Before conducting the analysis, the first thing to do is estimate location quotient analysis to find out the leading sector in South Sulawesi in $2016-2020$. The results found that the leading commodities in South Sulawesi which have very strong competitiveness are Nickel; Lac, Gums, and, Resin; Fish and Shrimp; and Cocoa;
Salt, Sulphur, and Calcium. Compared to the wider region, in Indonesia, the industrial sector has stable competitiveness and vegetable fats and oils have a high RCA index (Ahuja, 2020).

The results of this study found the coffee commodity in South Sulawesi has strong competitiveness and moderate market penetration. Based on the results of the Export Product Dynamics (EPD) analysis, the coffee commodity is in a rising star position, meaning that it can compete in reaching national and international export markets. This finding is consistent with prior research done in other countries about the competitiveness analysis of Indonesian and Vietnamese coffee exports in the ASEAN 5 market (Zuhdi Suharno, 2016). The results study found that coffee commodities in Indonesia had a high RCA index and the EPD results also found that coffee commodities in Indonesia were in the rising star quadrant.

Regarding the results of this study about EPD analysis in South Sulawesi, commodities in the retreat quadrant are not found. The results that examined whether Indonesia's export competitiveness got better after Indonesia was involved in ASEAN with case studies in Indonesia and China, found different things. The study found that most of Indonesia's export products in the Chinese market were categorized as a retreat, meaning that the commodity did not have dynamic competitiveness and could not experience an increase in market share (Widyasanti, 2010). This condition occurs because the study examines a larger area and compares it with countries that have high export potential in the world so that if a comparison between Indonesia and China occurs, it is still found that some Indonesian export products in the Chinese market are classified as retreats.

\section{CONCLUSION}

The following conclusions may be derived from the findings of the research on mapping the competitiveness and market penetration of South Sulawesi Province's key commodities. 
There are 11 (eleven) leading export commodities of South Sulawesi Province, spread over 20 regencies/cities in the province.

From the eleven leading export commodities of South $\mathrm{Su}-$ lawesi, five commodities have a "very strong" average competitiveness in the last 5 years (nickel; lac, gums, and, resin; fish and shrimp; cocoa; and salt, sulfur, and calcium), followed by six commodities with "strong" competitiveness (coffee, tea, maté, and spices; processed meat and fish; residues and waste from the food industries; fruits; oil seeds; and sugars and sugar confectionery).

From the eleven leading export commodities of South Sulawesi province, four commodities have "high" market penetration power in the last 5 years (nickel; lac, gums, and, resin; fish and shrimp; and cocoa), followed by four commodities that have "medium" market penetration power (coffee, tea, maté, and spices; processed meat and fish; residues and waste from the food industries; and salt, sulfur, and calcium) and three commodities that have "low" market penetration power (fruits; oilseeds; and sugars and sugar confectionery).

After mapping, it was found that of the eleven leading export commodities of South Sulawesi Province four commodities have very strong competitiveness and high market penetration (nickel; lac, gums, and, resin; fish and shrimp; and cocoa) followed by one commodity that has very strong competitiveness but moderate market penetration (salt, sulfur, and calcium); then three commodities that have strong competitiveness and moderate market penetration (coffee, tea, maté, and spices; processed meat and fish; and residues and waste from the food industries); and three commodities that have strong competitiveness but low market penetration (fruits; oil seeds; sugars and sugar confectionery).

From the export product dynamic analysis there are 6 commodities; nickel; lac, gum, and resin; salt, sulfur, and calcium; fish and shrimp; sugars and sugar confectionery; and coffee, tea, maté, and spices in rising star position and there are five commodities in loss opportunity position; oil seeds; cocoa; fruits; preparations of meat and fish; and residues and waste from the food industries.

In following up on the results of this study, it is recommended that (i) a more comprehensive policy is needed to encourage a more optimal increase in competitiveness so that it can have a positive effect on the economic growth of South $\mathrm{Su}-$ lawesi province, (ii) the government needs to develop and expand opportunities for bilateral cooperation with non-traditional markets to increase the competitiveness and market penetration of these leading commodities, (iii) there is a need for a more comprehensive study of other competitiveness indicators so that local government policy-making can be more effective in achieving the objectives of the policy.

\section{References}

Ahuja, R., 2020. Revealed Comparative Advantages: A Study of India and ASEAN Economies.
Bano, S., Scrimgeour, F., 2012. The Export Growth and Revealed Comparative Advantage of the New Zealand Kiwifruit Industry. International Business Research 5, 73-82.

URL: https://www.ccsenet.org/journal/index.php/ibr/ article/view/14585

DOI: doi : 10.5539/ibr.v5n2p73

Batra, A., Khan, Z., 2005. Revealed Comparative Advantage: An Analysis For India and China. Indian Council For Research On International Economic Relations, New Delhi.

URL: http://www.icrier.org/pdf/wp168.pdf

Bhattacharyya, R., 2012. Revealed Comparative Advantage and Competitiveness: A Case Study For India In Horticultural Products. Journal Of European Economy, 22-37.

URL: http://dspace.wunu.edu.ua/bitstream/316497/31539/1/ BhattacharyyaR..pdf

Gallardo, J. L., 2005. Comparative Advantage, Economic Growrth and Free Trade. Revista de Economia Contemporânea 9 (2), 313-335.

URL: $\quad$ https://www.scielo.br/j/rec/a/ wZQKCDYD7prBdDJvpCyddFk/? lang=en

Riaz, B., 2011. Comparative Advantage, Exports and Economic Growth: An Issue of Causality, 1-64.

URL: https://www.diva-portal.org/smash/get/diva2:425665/ FULLTEXT01.pdf

Serin, V., Civan, A., 2008. Revealed Comparative Advantage and Competitiveness: A Case Study for Turkey towards the EU. Journal of Economic and Social Research 10 (2), 25-41.

URL: https://citeseerx.ist.psu.edu/viewdoc/download?doi= $10.1 .1 .568 .1868\{\&\}$ rep=rep $1\{\&\}$ type $=$ pdf

Seyoum, B., 2007. Revealed comparative advantage and competitiveness in services. Journal of Economic Studies 34 (5), 376-388.

URL: https://ideas.repec.org/a/eme/jespps/ v34y2007i5p376-388.html

Sheng, Y., Song, L., 2008. Comparative Advantage And Australia-China Bilateral Trade. Journal of Applied Economics and Policy 27 (1), 41-56.

URL: https://www.researchgate.net/publication/227659370_ Comparative_advantage_and_Australia-China_bilateral_ trade

DOI: http://dx.doi.org/10.1111/j.1759-3441.2008.tb01025.x

Utkulu, U., Seymen, D., 2004. Revealed Comparative Advantage and Competitiveness: Evidence for Turkey vis-à-vis the EU/15. European Trade Study Group 6th Annual Conference 15, 1-26.

URL: https://www.researchgate.net/publication/228697204_ Revealed_Comparative_Advantage_and_Competitiveness_ Evidence_for_Turkey_vis-a-vis_the_EU15

Widyasanti, A. A., 2010. Do Regional Trade Areas Improve Export Competitiveness?-a Case of Indonesia. Bulletin of Monetary Economics and Banking 13 (1), 1-18.

URL: https://www.researchgate.net/publication/312647714_ DO_REGIONAL_TRADE_AREAS_IMPROVE_EXPORT_COMPETITIVENESS_ -_A_CASE_OF_INDONESIA

Yue, C., Hua, P., 2002. Does comparative advantage explains export patterns in China? China Economic Review 13 (2-3), 276-296.

URL: https://econpapers.repec.org/RePEc: eee: chieco:v:13: $y: 2002: i: 2-3: p: 276-296$

Zuhdi, F., Suharno, 2015. Competitiveness Analysis Of Indonesia And Vietnam Coffe Export in ASEAN 5 Market. Habitat 26 (3), 152-162.

URL: https://www.researchgate.net/publication/314162025_ ANALISIS_DAYA_SAING_EKSPOR_KOPI_INDONESIA_DAN_VIETNAM_ DI_PASAR_ASEAN_5 